\title{
Correction: Frequency, course and correlates of alcohol use from adolescence to young adulthood in a Swiss community survey
}

Hans-Christoph Steinhausen*, Susanne Eschmann, Annina Heimgartner, Christa Winkler Metzke

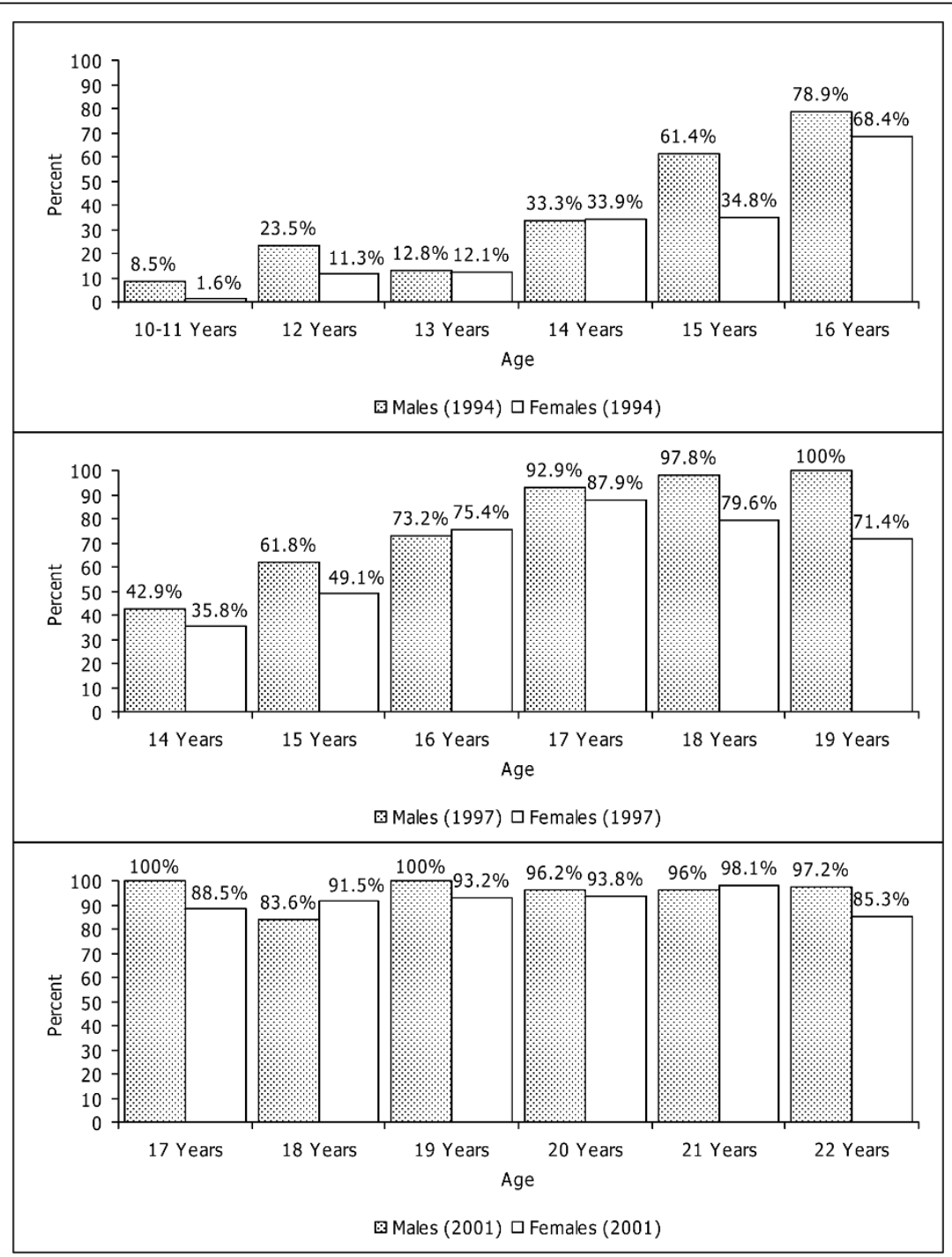

Figure 1 Frequencies of alcohol consumption ( $\geq 1$ glass of alcohol) at three times.

* Correspondence: hc.steinhausen@kjpd.uzh.ch

Department of Child and Adolescent Psychiatry, University of Zurich,

Neumuensterallee 9, CH 8032 Zurich, Switzerland 


\section{Correction}

After the publication in this journal [1] we became aware of the fact that the article contained wrong data in figure 1 . This correction contains the revised figure 1. We regret any inconvenience that this inaccuracy in the presentation of the figure might have caused.

Received: 7 December 2009

Accepted: 18 February 2010 Published: 18 February 2010

\section{References}

1. Steinhausen H-C, Eschmann S, Heimgartner A, Winkler Metzke C:

Frequency, course and correlates of alcohol use from adolescence to young adulthood in a Swiss community survey. BMC Psychiatry 2008, 8:5.

\section{Pre-publication history}

The pre-publication history for this paper can be accessed here:http://www. biomedcentral.com/1471-244X/10/15/prepub

Cite this article as: Steinhausen et al:: Correction: Frequency, course and correlates of alcohol use from adolescence to young adulthood in a Swiss community survey. BMC Psychiatry 2010 10:15.

Submit your next manuscript to BioMed Central and take full advantage of:

- Convenient online submission

- Thorough peer review

- No space constraints or color figure charges

- Immediate publication on acceptance

- Inclusion in PubMed, CAS, Scopus and Google Scholar

- Research which is freely available for redistribution

Submit your manuscript at www.biomedcentral.com/submit 